\title{
SOIL NITROGEN DYNAMICS AFTER BRACHIARIA DESICCATION $^{(1)}$
}

\author{
Gustavo Castoldi ${ }^{(2)}$, Jhônatas Gomes dos Reis ${ }^{(3)}$, Laércio Augusto Pivetta ${ }^{(2)}$ \& Ciro \\ Antonio Rosolem ${ }^{(4)}$
}

\begin{abstract}
SUMMARY
Brachiaria species, particularly $B$. humidicola, can synthesize and release compounds from their roots that inhibit nitrification, which can lead to changes in soil nitrogen $(\mathrm{N})$ dynamics, mainly in $\mathrm{N}$-poor soils. This may be important in croplivestock integration systems, where brachiarias are grown together with or in rotation with grain crops. The objective of the present study was to determine whether this holds true in N-rich environments and if other Brachiaria species have the same effect. The soil $\mathrm{N}$ dynamics were evaluated after the desiccation of the species B. brizantha, B. decumbens, B. humidicola, and B. ruziziensis, which are widely cultivated in Brazil. The plants were grown in pots with a dystroferric Red Latosol in a greenhouse. Sixty days after sowing, the plants were desiccated using glyphosate herbicide. The plants and soil were analyzed on the day of desiccation and 7, 14, 21 and 28 days after desiccation. The rhizosphere soil of the grasses contained higher levels of organic matter, total $\mathrm{N}$ and ammonium than the non-rhizosphere soil. The $\mathrm{pH}$ was lowest in the rhizosphere of $B$. humidicola, which may indicate that this species inhibits the nitrification process. However, variations in the soil ammonium and nitrate levels were not sufficient to confirm the suppressive effect of $B$. humidicola. The same was observed for $B$. brizantha, $B$. decumbens and B. ruziziensis, thereby demonstrating that, where $\mathrm{N}$ is abundant, none of the brachiarias studied has a significant effect on the nitrification process in soil.

Index terms: Brachiaria brizantha, Brachiaria decumbens, Brachiaria humidicola, Brachiaria ruziziensis, nitrification, rhizosphere.
\end{abstract}

(1) Part of Dissertation presented by the first author to the College of Agricultural Sciences, São Paulo State University - FCA/ UNESP. This research was supported by FAPESP (State of São Paulo Research Foundation). Received for publication on September 04, 2012 and approved on July 27, 2013.

(2) PhD student in Agronomy (Agriculture), FCA/UNESP. P.O. Box 237. Zip Code 18610-307 Botucatu (SP), Brazil. E-mail: castoldi@fca.unesp.br, laerciopivetta@fca.unesp.br

(3) Undergraduate student of Agronomy, FCA/UNESP. E-mail: jgdreis@fca.unesp.br

(4) Professor, Department of Crop Science, FCA/UNESP. E-mail: rosolem@fca.unesp.br 


\title{
RESUMO: DINÂMICA DO NITROGÊNIO NO SOLOAPÓS A DESSECAÇÃO DE BRACHIARIAS
}

\begin{abstract}
Espécies do gênero Brachiaria, particularmente a B. humidicola, podem sintetizar e liberar de suas raízes compostos que inibem o processo de nitrificação, o que pode provocar alterações na dinâmica do nitrogênio (N) no solo, principalmente em solos com baixa disponibilidade de N. Isso pode ser importante em sistemas com integração lavoura-pecuária, em que a forrageira é cultivada junto ou em rotação com culturas graníferas. Neste estudo, objetivou-se determinar se isso ocorre também em ambiente mais rico em $N$ e se outras espécies de Brachiaria têm o mesmo efeito. Para tal, avaliou-se a dinâmica do $N$ no solo após a dessecação de B. brizantha, B. decumbens, B. humidicola e B. ruziziensis, espécies amplamente cultivadas no Brasil. As plantas foram cultivadas em vasos com um Latossolo Vermelho distroférrico, em casa de vegetação. Sessenta dias após a semeadura, as plantas foram dessecadas com aplicação do herbicida glifosato. Foram realizadas análises de planta e solo, na data da dessecação e aos 7, 14, 21 e 28 dias após a dessecação. Os maiores teores de matéria orgânica, $N$-total e amônio foram encontrados no solo rizosférico das plantas. A rizosfera $d a \mathrm{~B}$. humidicola apresentou ainda o menor valor de $\mathrm{pH}$, o que poderia estar associado ao efeito supressivo dessa espécie no processo de nitrificação. Entretanto, as variações encontradas nos teores de amônio e nitrato não foram suficientes para confirmar o efeito supressivo da B. humidicola. Essa observação se repetiu para B. brizantha, B. decumbens $e$ B. ruziziensis, demonstrando que, em condições de boa disponibilidade de $N$, nenhuma das brachiarias avaliadas influencia significativamente o processo de nitrificação no solo.
\end{abstract}

Termos de indexação: Brachiaria brizantha, Brachiaria decumbens, Brachiaria humidicola, Brachiaria ruziziensis, nitrificação, rizosfera.

\section{INTRODUCTION}

Brachiaria species adapt well to various soil conditions, are easily established and produce considerable quantities of dry matter and are therefore widely used in various cropping systems (Timossi et al., 2007). Chemical treatments and the herbicide glyphosate in particular are commonly used as strategies of vegetation management in no-tillage systems (Oliveira Júnior et al., 2006). Research has suggested that Brachiaria species, and specifically Brachiaria humidicola, have the ability to inhibit biological nitrification in soil through the release of chemical compounds, thereby maintaining nitrogen $(\mathrm{N})$ as ammonium $\left(\mathrm{NH}_{4}^{+}\right)$for longer periods by delaying the oxidation of $\mathrm{NH}_{4}^{+}$to nitrate $\left(\mathrm{NO}_{3}{ }^{-}\right.$) (Ishikawa et al., 2003; Subbarao et al., 2007a). Brachiaria humidicola is recognized as one of the plants with the greatest capacity to inhibit biological nitrification in the soil (Subbarao et al., 2007a). Therefore, B. humidicola has been used as a model to characterize the suppressive ability of plants, which must have sufficient inhibitory activity to suppress soil nitrification and the emission of $\mathrm{N}_{2} \mathrm{O}$ (Subbarao et al., 2009). However, the presence or absence and intensity of this suppressive effect in soil depends on several factors, such as the soil moisture, temperature and type (Ipinmoroti et al., 2008), the N status of the plant (Subbarao et al., 2006a), the form (i.e., $\mathrm{NH}_{4}{ }^{+}$or $\mathrm{NO}_{3}{ }^{-}$) of $\mathrm{N}$ when applied and/or made available (Subbarao et al., 2007b,c), and especially the presence of $\mathrm{NH}_{4}{ }^{+}$in the rhizosphere, which is essential for the synthesis and release of biological nitrificationinhibiting compounds (BNIs) from the roots (Subbarao et al., 2007b,c; Subbarao et al., 2009).
Recently, Subbarao et al. (2009) isolated the main BNI from the roots of $B$. humidicola and elucidated the mechanism of inhibition. Called "Brachialactone", this compound is responsible for $60-90 \%$ of the suppressive activity of $B$. humidicola and it functions by blocking the action of Nitrosomonas. During the oxidation of $\mathrm{NH}_{4}{ }^{+}$to nitrite $\left(\mathrm{NO}_{2}{ }^{-}\right)$, at least one intermediate compound (hydroxylamine; $\mathrm{NH}_{2} \mathrm{OH}$ ), is formed. The oxidation of $\mathrm{NH}_{4}{ }^{+}$to $\mathrm{NH}_{2} \mathrm{OH}$ is mediated by the enzyme ammonia monooxygenase (AMO), and the oxidation of $\mathrm{NH}_{2} \mathrm{OH}$ to $\mathrm{NO}_{2}$ - is catalyzed by the enzyme hydroxylamine oxidoreductase (HAO). "Brachialactone" functions by inhibiting the AMO and HAO enzymatic pathways with a greater effect on AMO.

This ability to inhibit nitrification functions as a mechanism of adaptation to conserve and utilize $\mathrm{N}$ effectively in environments where $\mathrm{N}$ is the main limiting factor of growth and reproduction, and thus, this inhibitory effect is most likely related to the availability of $\mathrm{N}$, and particularly $\mathrm{N}-\mathrm{NH}_{4}{ }^{+}$, in the rooting medium (Ishikawa et al., 2003; Subbarao et al., 2006b,c). However, in the crop-livestock integration systems, brachiarias are grown together or in rotation with grain crops, where $\mathrm{N}$ availability is not a limiting factor.

Assuming that this effect on the nitrification process can interfere with the overall soil-plant $\mathrm{N}$ cycling system and may serve as a tool to improve the management of cropping systems, the $\mathrm{N}$ dynamics in the soil were evaluated after the desiccation of $B$. humidicola, B. brizantha, B. decumbens and $B$. ruziziensis, which are widely cultivated species in Brazil. 


\section{MATERIAL AND METHODS}

The experiment was conducted in a greenhouse at the College of Agricultural Sciences, Botucatu, SP, Brazil. During the evaluation period, the average maximum and minimum temperatures were 34.3 and $20.8{ }^{\circ} \mathrm{C}$, respectively, and the average relative humidity ranged from 51.2 to $83.1 \%$. The experimental design was in randomized blocks with a split plot design with four replicates. Four species of Brachiaria (B. brizantha cv. Marandu, B. decumbens, $B$. humidicola and $B$. ruziziensis) were grown and sampled on five dates $(0,7,14,21$, and 28 days after desiccation (DAD).

The plants were grown in PVC pots with closed bottoms that were filled with $12.6 \mathrm{dm}^{3}$ of dystroferric Red Latosol (Embrapa, 2006) taken from the 0.0-0.2 $\mathrm{m}$ layer. In the area where the soil was collected notillage common bean was planted and soil was sampled immediately after common bean harvest. The pots consisted of four PVC rings (width $20 \mathrm{~cm}$, height 10), to facilitate soil and root sampling. On the top of each ring an adhesive tape was attached half bent into the pot in order to form a $1.0 \mathrm{~cm}$ internal barrier against preferential water flow. Prior to the start of the experiment, dolomitic limestone (29\% CaO, $18 \%$ $\mathrm{MgO}$, with a total neutralizing power of $86 \%$ ) was applied at $0.53 \mathrm{~g} \mathrm{dm}^{-3}$ ( $6.68 \mathrm{~g}$ per pot) and the soil was wet-incubated for 30 days. After incubation, the soil was subjected to particle size (Embrapa, 1997) and chemical (Raij et al., 2001) analyses, including the determination of total N (Bremner \& Mulvaney, 1982). The results showed 539, 151 and $311 \mathrm{~g} \mathrm{dm}^{-3}$ of clay, silt and sand, respectively, a $\mathrm{pH}\left(\mathrm{CaCl}_{2} 1 \mathrm{~mol} \mathrm{~L}^{-1}\right)$ of 5.3 , $25 \mathrm{~g} \mathrm{dm}^{-3}$ of organic matter (OM), $1036 \mathrm{mg} \mathrm{dm}^{-3}$ total $\mathrm{N}$, $8.0 \mathrm{mg} \mathrm{dm}^{-3} \mathrm{P}_{\text {resin }}, 0.8 \mathrm{mmol}_{\mathrm{c}} \mathrm{dm}^{-3} \mathrm{~K}, 30 \mathrm{mmol}_{\mathrm{c}} \mathrm{dm}^{-3}$ $\mathrm{Ca}, 20 \mathrm{mmol}_{\mathrm{c}} \mathrm{dm}^{-3} \mathrm{Mg}, 51 \mathrm{mmol}_{\mathrm{c}} \mathrm{dm}^{-3} \mathrm{SB}$, a cation exchange capacity of $81 \mathrm{mmol}_{\mathrm{c}} \mathrm{dm}^{-3}$ and $62 \%$ base saturation.

After liming, the soil was fertilized with N, P and $\mathrm{K}$ at doses of 100,150 and $120 \mathrm{mg} \mathrm{kg}^{-1}$, respectively, as ammonium nitrate, single superphosphate and potassium chloride. A total of 12 pre-germinated seeds were added to each pot, and three plants were retained after thinning seven days after sowing. At the tillering stage (21 days after sowing), a dressing of $50 \mathrm{mg} \mathrm{dm}^{-3}$ $\mathrm{N}$ as urea was added. Throughout the experimental period, including after drying, irrigation was performed to maintain $70 \%$ of the water retention capacity. Sixty days after sowing, the plants were desiccated with glyphosate herbicide at a dose equivalent to $1,440 \mathrm{~g} \mathrm{ha}^{-1}$ of active ingredient $\left(2.0 \mathrm{~kg} \mathrm{ha}^{-1}\right.$ Roundup $\mathrm{WG}^{\circledR}$, Monsanto, St. Louis, MO). The glyphosate herbicide was applied by spraying pressurized $\mathrm{CO}_{2}$ and a mixture volume of $150 \mathrm{~L} \mathrm{ha}^{-1}$.

Evaluations were performed at weekly intervals following the desiccation of the Brachiaria plants. The first evaluation was performed on the morning after plant desiccation (0), and the others 7, 14, 21 and 28
DAD. The plant shoots were cut close to the soil surface, washed with distilled water, placed in paper bags and dried in a convection oven at $55^{\circ} \mathrm{C}$ to constant weight. After drying, the shoots (stem + leaves) and root dry mass was weighed and the material was ground and $\mathrm{N}$ contents determined to calculate the amount of $\mathrm{N}$ accumulated in the plants (shoots + roots). The total $\mathrm{N}$ was determined via sulfur digestion and distillation in a steam distiller.

The soil was separated into rhizospheric and nonrhizospheric parts after cutting the plants. The pots were placed in plastic bowls and the PVC rings that formed the pots were loosened and removed. From the resulting soil clod, the non-rhizospheric soil and roots were carefully separated into two other plastic bowls by gently shaking the root system. Then the roots were manually separated from the rhizospheric soil, i.e., the remaining soil attached to the roots (layer of $\pm 2 \mathrm{~mm}$ ) after the first separation. The same cleaning and drying procedures as applied to the stem + leaves were applied to roots.

The non-rhizospheric soil was homogenized and a sample was collected and separated through a sieve (2 mm mesh). All soil from the rhizosphere was sieved due to the small amount that was obtained. Each type of soil was subsequently divided into two subsamples: one that was immediately placed in a freezer at $-15^{\circ} \mathrm{C}$ to maintain inorganic $\mathrm{N}$ levels and a second sample that was air-dried for $\mathrm{pH}$ and $\mathrm{OM}$ analyses.

The $\mathrm{NH}_{4}{ }^{+}$and $\mathrm{NO}_{3}{ }^{-}\left(\mathrm{NO}_{2}+\mathrm{NO}_{3}{ }^{-}\right)$concentrations in the frozen soil samples were determined by extraction with $\mathrm{KCl}$ followed by two distillations according to Keeney \& Nelson (1982). The total N levels were determined via sulfur digestion and subsequent distillation (Bremner \& Mulvaney, 1982). Because the soil was moist, the mass was used instead of the volume so that the soil moisture in each sample could be determined in the analysis, which was necessary for the subsequent correction of the results. The $\mathrm{pH}$ and $\mathrm{OM}$ levels were determined using the air-dried soil samples as described by Raij et al. (2001).

The results were subjected to analysis of variance. When significant differences $(p<0.05)$ were determined, the species were compared using a t test (least significant difference - LSD), $(\mathrm{p}<0.05)$, and the data were compared by regression analysis. The results of soil analysis were analyzed in a factorial split plot design because the soil type (rhizospheric and non-rhizospheric soil), date and species were factors in the analysis.

\section{RESULTS}

The amount of $\mathrm{N}$ accumulated in the plants was affected by the interaction of the evaluation date (DAD) $\mathrm{x}$ species (B. brizantha, B. decumbens, B. humidicola and B. ruziziensis). Brachiaria humidicola and $B$. 
ruziziensis had the lowest and highest amounts of accumulated $\mathrm{N}$, respectively. However, regardless of the accumulated amount, the four species showed a linear decrease in $\mathrm{N}$ as a function of time after desiccation (with glyphosate) (Figure 1).

The interaction of evaluation date $\mathrm{x}$ species $\mathrm{x}$ soil type (rhizospheric and non-rhizospheric) was not significant for variables found in the soil assessment, although the species $\mathrm{x}$ soil and evaluation date $\mathrm{x}$ soil interactions were significant for $\mathrm{pH}$ and $\mathrm{NO}_{3}^{-}$, respectively. The concentrations of $\mathrm{NO}_{3}{ }^{-}$were affected by the species and the levels of $\mathrm{NH}_{4}{ }^{+}$were influenced by the evaluation date, species and soil. The OM contents and total $\mathrm{N}$ values differed between the soils, and the amount of total $\mathrm{N}$ differed among the evaluation dates.

In $B$. humidicola, the $\mathrm{pH}$ was lower in the rhizospheric than the non-rhizospheric soil. The $\mathrm{pH}$ of the B. humidicola rhizosphere was also lower than that in the rhizospheres of the other species (Table 1). Differences between the rhizospheric and nonrhizospheric soils were also observed for OM, total N and $\mathrm{NH}_{4}{ }^{+}$; these values were higher in the rhizospheric soils, regardless of the Brachiaria species (Table 2).

Although the value of total $\mathrm{N}$ determined in the rhizosphere was higher than that found in the nonrhizospheric soil, the change in total $\mathrm{N}$ after desiccation was similar in both soil categories and increased over time after this event (Figure 2). Similarly, the change in the concentration of $\mathrm{NH}_{4}{ }^{+}$ was similar in both soil categories and decreased significantly over time after the desiccation of the species (Figure 3). The levels of $\mathrm{NO}_{3}{ }^{-}$in the rhizospheric and non-rhizospheric soil increased linearly over time after desiccation (Figure 4). Although there was no significant difference between the soils during the evaluation period, the

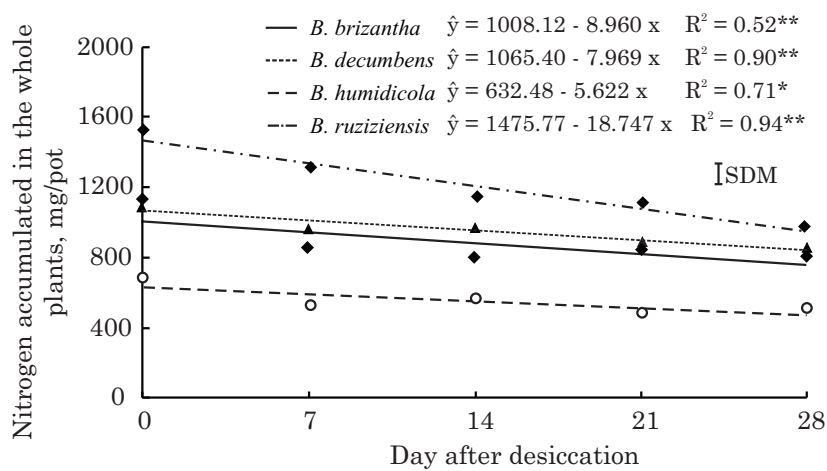

Figure 1. Nitrogen accumulated in the whole plants (shoots + roots) of $B$. brizantha, B. decumbens, $B$. humidicola and $B$. ruziziensis as a function of time after glyphosate desiccation. * and ** significant by the $\mathrm{F}$ test at 5 and $1 \%$, respectively. The vertical bar represents the standard deviation of the mean (SDM) obtained from the t test (LSD) at $5 \%$. concentration of $\mathrm{NO}_{3}$ - in the rhizosphere increased by $35.4 \mathrm{mg} \mathrm{dm}^{-3}$, whereas the increase in the nonrhizospheric soil was $16.7 \mathrm{mg} \mathrm{dm}^{-3}$.

There were significant changes in the levels of soil $\mathrm{NH}_{4}{ }^{+}$and $\mathrm{NO}_{3}{ }^{-}$over time after plant desiccation. For these variables, the $\mathrm{DAD} x$ species interaction was not significant at the $5 \%$ level. However, one of the main objectives of the study was to determine the effects of Brachiaria on the nitrification process. Therefore, these results are presented to demonstrate the behavior of $\mathrm{NH}_{4}{ }^{+}$and $\mathrm{NO}_{3}{ }^{-}$in the soil after the desiccation of each Brachiaria species (Figure 5).

The levels of $\mathrm{NH}_{4}{ }^{+}$determined in the soil at the time of desiccation were similar among the species, although the lowest level was observed in the soil cultivated with $B$. humidicola. In the other evaluations, the soil $\mathrm{NH}_{4}{ }^{+}$levels decreased similarly among the species (Figure 4a). The soil $\mathrm{NO}_{3}{ }^{-}$levels showed a similar behavior for all species with increasing concentrations over time after desiccation (Figure 4b). Although the trends for soil $\mathrm{NO}_{3}$ - observed in the four Brachiaria species were similar, the levels of $\mathrm{NO}_{3}{ }^{-}$were highest in the soil with $B$. humidicola in all evaluations. The lowest levels of $\mathrm{NO}_{3}$ - were observed in the soil cultivated with $B$. ruziziensis, and the soils cultivated with $B$. brizantha and $B$. decumbens showed similar intermediate levels.

Table 1. pH values in the rhizospheric and nonrhizospheric soils of $B$. brizantha, B. decumbens, $B$. humidicola and $B$. ruziziensis (mean of five evaluations)

\begin{tabular}{lcc}
\hline \multirow{2}{*}{ Specie } & \multicolumn{2}{c}{ Soil $\mathbf{p H}^{(\mathbf{1})}$} \\
\cline { 2 - 3 } & Rhizosphere & Non-rhizosphere \\
\hline B. brizantha & $4.95 \mathrm{aA}$ & $4.95 \mathrm{aA}$ \\
B. decumbens & $5.00 \mathrm{aA}$ & $4.95 \mathrm{aA}$ \\
B. humidicola & $4.75 \mathrm{bB}$ & $4.95 \mathrm{aA}$ \\
B. ruziziensis & $5.00 \mathrm{aA}$ & $5.00 \mathrm{aA}$ \\
\hline
\end{tabular}

(1) $\mathrm{pH}$ in $1 \mathrm{~mol} \mathrm{~L}^{-1} \mathrm{CaCl}_{2}$. Means followed by the same letters (lowercase in columns and uppercase in rows) are not significantly different according to the test (LSD) at $5 \%$.

Table 2. Organic matter (OM), total-N and ammonium $\left(\mathrm{NH}_{4}{ }^{+}-\mathrm{N}\right)$ in the rhizospheric and non-rhizospheric soils of Brachiaria sp. (mean of five evaluation times and four brachiaria species)

\begin{tabular}{cccc}
\hline \multicolumn{1}{c}{ Soil } & OM & Total-N & NH $_{4}{ }^{+}-\mathbf{N}$ \\
\hline & $\mathrm{g} \mathrm{dm}^{-3}$ & \multicolumn{2}{c}{$\mathrm{mg} \mathrm{dm}^{-3}$} \\
\cline { 3 - 4 } Rhizosphere & $23.47 \mathrm{a}$ & $1157.7 \mathrm{a}$ & $8.99 \mathrm{a}$ \\
Non-rhizosphere & $23.13 \mathrm{~b}$ & $1137.6 \mathrm{~b}$ & $7.11 \mathrm{~b}$ \\
\hline
\end{tabular}

Means followed by same letters in the columns are not significantly different according to the $t$ test (LSD) at $5 \%$. 


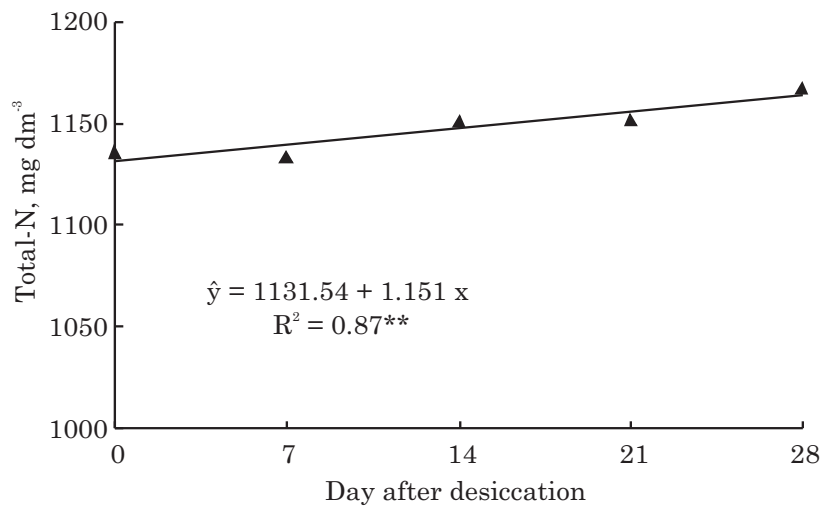

Figure 2. Total nitrogen (Total-N) in the soil as a function of time after the desiccation of Brachiaria sp. with glyphosate (mean of rhizosphere and nonrhizosphere soil of four brachiaria species). ** significant by the $\mathrm{F}$ test at $1 \%$.

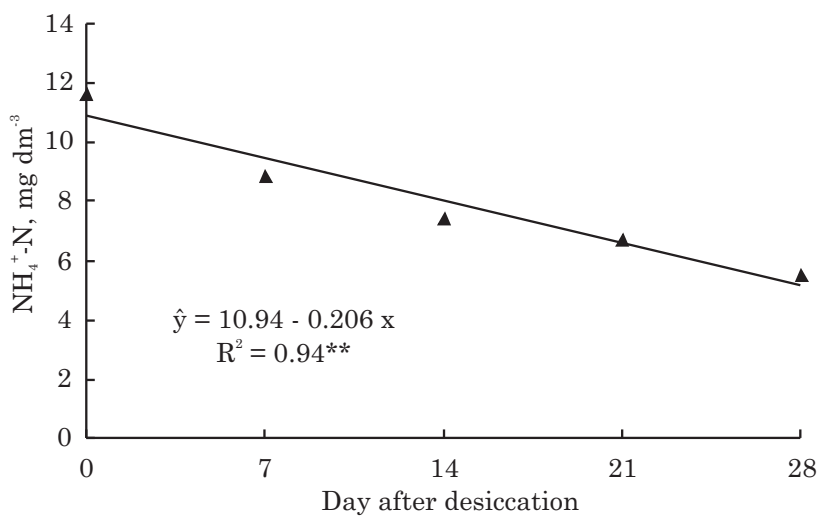

Figure 3. Ammonium $\left(\mathrm{NH}_{4}{ }^{+}-\mathrm{N}\right)$ in the soil as a function of time after the desiccation of Brachiaria sp. with glyphosate (mean of rhizosphere and nonrhizosphere soil of four brachiaria species). ** significant by the $\mathrm{F}$ test at $1 \%$.

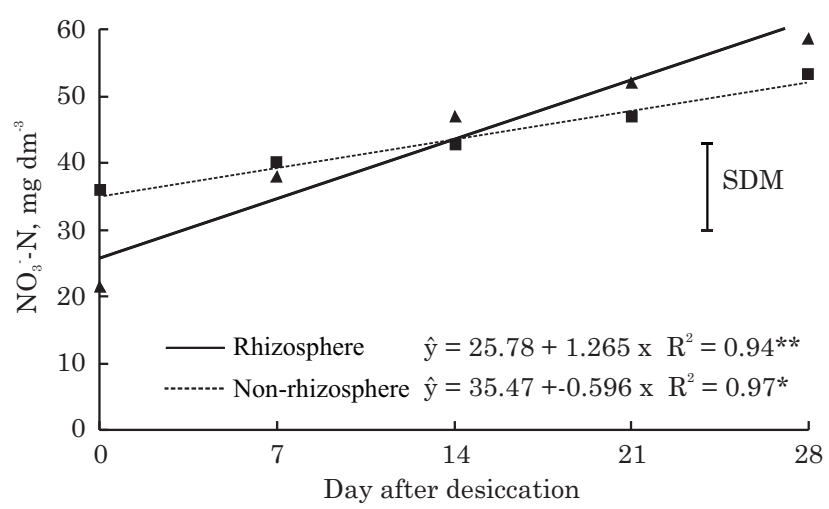

Figure 4. Nitrate $\left(\mathrm{NO}_{3}^{-}-\mathrm{N}\right)$ in the rhizospheric and nonrhizospheric soils of Brachiaria sp. as a function of time after desiccation with glyphosate (mean of four brachiaria species). * and ** significant by the $F$ test at 5 and $1 \%$, respectively. The vertical bar represents the standard deviation of the mean (SDM) obtained from the t test (LSD) at $5 \%$.
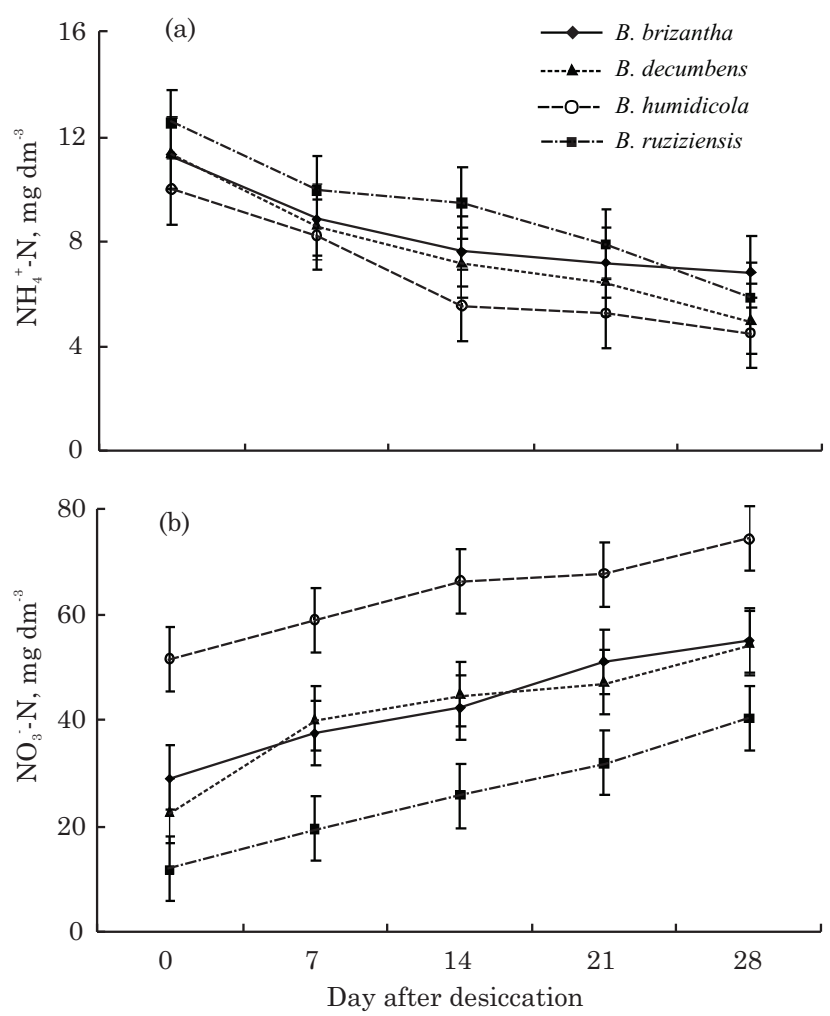

Figure 5. Ammonium $\left(\mathrm{NH}_{4}{ }^{+}-\mathrm{N}\right)$ (a) and nitrate $\left(\mathrm{NO}_{3}^{--}\right.$ N) (b) in the soil after desiccation of $B$. brizantha, $B$. decumbens, B. humidicola and B. ruziziensis with glyphosate (mean of rhizosphere and nonrhizosphere soil). Vertical bars indicate the SDM from the t test (LSD) at $5 \%$.

\section{DISCUSSION}

The reduction of the amount of accumulated $\mathrm{N}$ in Brachiaria as a function of time after desiccation (Figure 1) most likely occurred due to the loss of $\mathrm{N}$ from both the shoots and roots. N losses from the shoots of plants mainly occur in the form of $\mathrm{NH}_{3}$ and may vary according to the species, stage of development, availability of $\mathrm{N}$ in the soil, and stress level of the plant (Schjoerring et al., 1998). The potential for the release of $\mathrm{NH}_{3}$ - is greatest during the development of senescence (Vallis \& Keating, 1994) due to increased levels of endogenous $\mathrm{NH}_{4}{ }^{+}$in the plant during this phase (Schjoerring et al., 1998). Thus, the release of $\mathrm{NH}_{3}$ - from shoots can be increased by glyphosate due to the induction of senescence (Damin et al., 2008) as well as the mode of action of glyphosate, resulting in $\mathrm{NH}_{4}{ }^{+}$accumulation in the plant (Duke \& Hoagland, 1985).

The exudation of nitrogenous compounds by roots can also be affected by glyphosate to become an important route of N loss from the plant. Several studies have reported an increase in the exudation of amino acids (valine, isoleucine and glycine) and proteins in common bean (Phaseolus vulgaris L.) and 
soybean (Glycine $\max ($ L.) Merrill) plants after glyphosate application (Liu et al., 1997; Kremer et al., 2005). Using ${ }^{15} \mathrm{~N}$ as a tracer in the nutrient solution, Damin et al. (2010a) found that applying glyphosate led to an increase in $\mathrm{N}$ exudation from $B$. decumbens roots of $70 \%$ compared to control plants (without glyphosate application) 11 days after herbicide use. Damin et al. (2008) observed an increase in $\mathrm{N}$ derived from fertilizer in the soil and a reduction of $\mathrm{N}$ in the plant after glyphosate was applied to $B$. decumbens and millet (Pennisetum glaucum), respectively, indicating that the herbicide increased the root exudation and/or release of $\mathrm{N}$.

One hypothesis regarding the relatively low $\mathrm{pH}$ values observed in the rhizosphere of $B$. humidicola (Table 1) would be that this species absorbs $\mathrm{NH}_{4}{ }^{+}$ preferentially. $\mathrm{N}$ is absorbed by the roots of plants as $\mathrm{NH}_{4}{ }^{+}$or $\mathrm{NO}_{3}$, and the form of $\mathrm{N}$ that is absorbed can affect the $\mathrm{pH}$ of the rhizosphere (Nye, 1981; Gijsman, 1990). The absorption of $\mathrm{NH}_{4}{ }^{+}$leads to a higher level of cations than anions in the toot cells. Consequently, $\mathrm{H}^{+}$ions are exuded to regulate the cytosolic $\mathrm{pH}$ and balance the charge, thereby decreasing the rhizosphere $\mathrm{pH}$. In contrast, when plants absorb $\mathrm{NO}_{3}$, there is an influx of $\mathrm{H}^{+}$(or an efflux of $\mathrm{OH}^{-}$), and the $\mathrm{pH}$ of the rhizosphere increases (Nye, 1981; Mengel \& Kirkby, 2001).

The presence of $\mathrm{NH}_{4}{ }^{+}$in the roots and the physiological consequences associated with $\mathrm{N}$ absorption, such as the acidification of the rhizosphere, appear to play important roles in the synthesis and release of BNIs by the roots of B. humidicola (Subbarao et al., 2007c, 2009). The regulatory role of $\mathrm{NH}_{4}{ }^{+}$in the synthesis and release of BNIs appears to be adapted to protect $\mathrm{NH}_{4}{ }^{+}$from nitrifying agents and is thus a key factor in the evolutionary success of BNI production as a mechanism of plant adaptation (Subbarao et al., 2007c). Thus, the lower $\mathrm{pH}$ observed in the rhizosphere of $B$. humidicola could also be attributed to its nitrification inhibition mechanism, at least in the rhizospheric region.

The chemical composition of the rhizospheric soil differed from that of the non-rhizospheric soil mainly due to the differential absorption of water and nutrients, changes in $\mathrm{pH}$, the exudation of organic compounds by the roots and a greater intensity of microbial activity, as determined by Dinkelaker et al. (1993). Compared with the non-rhizospheric soil, the rhizospheric region usually has high concentrations of organic compounds, including amino acids, sugars, organic acids, lipids, proteins, and enzymes (Ali et al., 2000). The concentrations and proportions of these components can vary considerably depending on the plant species and substrate characteristics (Lorenz et al., 1994).

A notable feature of the rhizosphere is the deposition of organic carbon via exudates and/or decomposition of dead tissue, which may account for up to $40 \%$ of the total input of $\mathrm{C}$ to the soil and is considered the major driver of microbial processes (Jones et al., 2009). This deposition of organic carbon is in agreement with the higher OM contents observed in the rhizospheric soils in relation to the nonrhizospheric soils (Table 2).

Root exudation also has important implications for the availability of $\mathrm{N}$, which may explain the larger amounts of total $\mathrm{N}$ determined in the rhizosphere (Table 2). Although root exudates predominantly consist of carbon compounds, exudates can also contain significant amounts of $\mathrm{N}$, which become available in the rhizosphere and can be used by microorganisms or recaptured by the plants (Bertin et al., 2003; Uren, 2007).

In the soil, the total $\mathrm{N}$ (Figure 2) showed an inverse relationship with $\mathrm{N}$ accumulated in the plants after desiccation (Figure 1). Thus, this increase may have occurred due to the exudation of nitrogenous compounds and the detachment and decomposition of senescent roots, both of which can result from the action of glyphosate (Kremer et al., 2005; Damin et al., 2010a,b). The action of glyphosate stimulates the exudation of nitrogenous compounds by roots (Kremer et al., 2005; Damin et al., 2010a), and $\mathrm{NH}_{4}{ }^{+}$is one of the principal nitrogenous compounds exuded by roots (Paynel et al., 2001), which may explain why a higher level of $\mathrm{NH}_{4}{ }^{+}$was found in the rhizospheric soil, considering that this ion is not easily diffused.

Regardless of the glyphosate half-life, various studies have investigated the effects of glyphosate on the microbial community. A study using culture medium reported that glyphosate has harmful effects on microorganisms (Hernández et al., 1999). However, other studies showed that the application of currently recommended glyphosate doses is harmless to soil microbial communities (Busse et al., 2001; Mijangos et al., 2009). Glyphosate was shown to have no effect on the nitrification process (Stratton \& Steward, 1991). Therefore, the effect of glyphosate on the nitrification process can be ignored in the present study, and thus, the $\mathrm{NH}_{4}{ }^{+}$and $\mathrm{NO}_{3}{ }^{-}$levels observed in the soil are solely related to the effects of the Brachiaria species.

The plants can be inferred to have no inhibitory effect on the nitrification process because $\mathrm{NH}_{4}{ }^{+}$was found in the same proportion in both soils as seen in the linear decrease of $\mathrm{NH}_{4}{ }^{+}$observed in both the rhizospheric and non-rhizospheric soils (Figure 3). If there was a suppressive effect, the impact would be small and similar among the species. Herman et al. (2006) also found similar rates of nitrification in the rhizospheric and non-rhizospheric soils of Avena bartata (an annual grass common in the forests of California, USA).

Another indication that plants do generally not significantly affect soil nitrification is the linear increase in the $\mathrm{NO}_{3}$ - concentration observed in the rhizospheric and non-rhizospheric soils (Figure 4). From the first evaluation 0 DAD until $28 \mathrm{DAD}$, the $\mathrm{NH}_{4}{ }^{+}$in the soil decreased by $5.8 \mathrm{mg} \mathrm{dm}{ }^{-3}$. This 
reduction does not explain the significant increases in $\mathrm{NO}_{3}{ }^{-}$in the rhizospheric and non-rhizospheric soils, which were 35.4 and $16.7 \mathrm{mg} \mathrm{dm}^{-3}$, respectively. This pattern suggests that much of the $\mathrm{NO}_{3}{ }^{-}$was derived from the decomposition of excised and/or senescent roots and the subsequent mineralization of $\mathrm{N}$. The greater increase in the $\mathrm{NO}_{3}$ concentration in the rhizosphere was most likely due to a higher gross rate of mineralization in the rhizospheric region, which, depending on the species and the environment, can be 10 times higher than in non-rhizospheric soil (Herman et al., 2006).

The similar soil $\mathrm{NH}_{4}{ }^{+}$concentrations noted for all species and the decreasing trend after plant desiccation provide additional evidence that $B$. humidicola had no suppressive effect on the nitrification process. These observations contrast with several reports that BNIs are capable of inhibiting nitrification (Ishikawa et al., 2003; Subbarao et al., $2007 b, c)$. However, several aspects should be considered in these reports, mainly, that $\mathrm{N}$ availability was limited in all experiments, which stimulated the release of BNI compounds. Under field conditions, nitrification and the emission of $\mathrm{N}_{2} \mathrm{O}$ are only suppressed in B. humidicola pastures after the third year of cultivation (Subbarao et al., 2009).

Based on the cumulative results, it can be assumed that the data obtained in this study are more likely related to the amount of $\mathrm{N}$ absorbed and accumulated by the species (Figure 1) than to any effect on nitrification. For example, B. ruziziensis absorbed and accumulated twice as much $\mathrm{N}$ as $B$. humidicola, whereas $B$. brizantha and B. decumbens absorbed and accumulated similar intermediate amounts of $\mathrm{N}$. This absorption pattern explains the levels of $\mathrm{NO}_{3}$ - found in the soil.

\section{CONCLUSIONS}

1. No significant suppressive effect on the nitrification process was detected for B. humidicola or any of the studied species after desiccation with glyphosate.

2. Growing brachiarias in soil with non-limiting $\mathrm{N}$ availability is unlikely to result in a suppressive effect on nitrification when the grasses are desiccated with glyphosate.

\section{ACKNOWLEDGEMENTS}

We thank the FAPESP (State of São Paulo Research Foundation) for funding the present project and for the Master's grant to the first author, and to the CNPq (National Council for Scientific and Technological Development) for a scholarship to the second author.

\section{LITERATURE CITED}

ALI, I.A.; KAFKAFI, U.; YAMAGUCHI, I.; SUGIMOTO, Y. \& INANAGA, S. Growth, transpiration, root-born cytokinins and gibberellins, and nutrient compositional changes in sesame exposed to low root zone temperature under different ratios of nitrate: ammonium supply. J. Plant Nutr., 23:123-140, 2000.

BERTIN, C.; YANG, X.H. \& WESTON, L. The role of root exudates and allelochemicals in the rhizosphere. Plant Soil, 256:67-83, 2003.

BREMNER, J.M. \& MULVANEY, C.S. Nitrogen: total. In: PAGE, A.L.; MILLER, R.H. \& KEENEY, D.R., eds. Methods of soil analysis. 2.ed. Madison, American Society of Agronomy, 1982. Part 2. p.595-624.

BUSSE, M.D.; RATCLIFF, A.W.; SHESTAK, C.J. \& POWERS, R.F. Glyphosate toxicity and the effects of long-term vegetation control on soil microbial communities. Soil Biol. Biochem., 33:1777-1789, 2001.

DAMIN, V.; FRANCO, H.C.J.; MORAES, M.F.; FRANCO, A. \& TRIVELIN, P.C.O. Nitrogen loss in Brachiaria decumbens after application of glyphosate or glufosinate-ammonium. Sci. Agric., 65:402-407, 2008.

DAMIN, V.; TRIVELIN, P.C.O.; CARVALHO, S.J.P.; MORAES, M.F. \& BARBOSA, T.G. Herbicide application increases nitrogen $\left({ }^{15} \mathrm{~N}\right)$ exudation and root detachment of Brachiaria decumbens Stapf. Plant Soil, 334:511-519, 2010a.

DAMIN, V.; TRIVELIN, P.C.O.; FRANCO, H.C.J. \& BARBOSA, T.G. Nitrogen $\left({ }^{15} \mathrm{~N}\right)$ loss in the soil-plant system after herbicide application on Pennisetum glaucum. Plant Soil, 328:245-252, $2010 b$.

DINKELAKER, B.; HAHN, G.; RÖMHELD, V.; WOLF, G.A. \& MARSCHNER, H. Non-destructive methods for demonstrating chemical changes in the rhizosphere: I. Description of methods. In: BARROW, N.J., ed. Plant nutrition from genetic engineering to field practice. Dordrecht, Klumer Academic, 1993. p.71-74 (Developments in Plant and Soil Sciences, 45)

DUKE, S.O. \& HOAGLAND, R.E. Effects of glyphosate on metabolism of phenolic compounds. In: GROSSBARD, E. \& ATKINSON, D., eds. The herbicide glyphosate. London, Butterworths, 1985. p.75-91.

EMPRESA BRASILEIRA DE PESQUISA AGROPECUÁRIA EMBRAPA. Manual de métodos de análises de solos. 2.ed. Rio de Janeiro, 1997. 212p.

EMPRESA BRASILEIRA DE PESQUISA AGROPECUÁRIA EMBRAPA. Sistema brasileiro de classificação de solos. Brasília, 2006. 412p.

GIJSMAN, A.J. Rhizosphere $\mathrm{pH}$ along different root zones of Douglas-fir (Pseudotsuga menziesii), as affected by source of nitrogen. Plant Soil, 124:161-167, 1990.

HERMAN, D.J.; JOHNSON, K.K.; JAEGER, C.H.; SCHWARTZ, E. \& FIRESTONE, M.K. Root influence on nitrogen mineralization and nitrification in Avena barbata rhizosphere soil. Soil Sci. Soc. Am. J., 70:1504-1511, 2006. 
HERNÁNDEZ, A.; GARCIA-PLAZAOLA, J.I. \& BECERRIL, J.M. Glyphosate effects on phenolic metabolism of nodulated soybean (Glycine $\max$ L. Merrill). J. Agric. Food Chem., 47:2920-2925, 1999.

IPINMOROTI, R.R.; WATANABE, T. \& ITO, O. Effect of Brachiaria humidicola root exudates, rhizosphere soils, moisture and temperature regimes on nitrification inhibition in two volcanic ash soils of Japan. World J. Agric. Sci., 4:106-113, 2008.

ISHIKAWA, T.; SUBBARAO, G.V.; ITO, O. \& OKADA, K. Suppression of nitrification and nitrous oxide emission by the tropical grass Brachiaria humidicola. Plant Soil, 255:413-419, 2003.

JONES, D.L.; NGUYEN, C. \& FINLAY, R.D. Carbon flow in the rhizosphere: carbon trading at the soil-root interface. Plant Soil, 321:5-33, 2009.

KEENEY, D.R. \& NELSON, D.W. Nitrogen: inorganic forms. In: PAGE, A.L.; MILLER, R.H. \& KEENEY, D.R., eds. Methods of soil analysis. 2.ed. Madison, American Society of Agronomy, 1982. Part 2. p.625-642.

KREMER, R.J.; MEANS, N.E. \& KIM, S. Glyphosate affects soybean root exudation and rhizosphere microorganisms. Inter. J. Environ. Anal. Chem., 85:11651174, 2005 .

LIU, L.; PUNJA, Z.K. \& RAHE, J.E. Altered root exudation and suppression of induced lignification as mechanisms of predisposition by glyphosate of bean roots (Phaseolus vulgaris L.) to colonization by Pythium spp. Physiol. Molec. Plant Pathol., 51:111-127, 1997.

LORENZ, S.E.; HERMON, R.E. \& McGRATH, S.P. Differences between soil solution obtained from rhizosphere and nonrhizosphere soil by water displacement and soil centrifugation. Eur. J. Soil Sci., 45:431-438, 1994

MENGEL, K. \& KIRKBY, E.A. Principles of plant nutrition. Dordrecht, Kluwer Academic, 2001. 655p.

MIJANGOS, I.; BECERRIL, J.M.; ALZIBU, I.; EPELDE, L. \& GARBISU, C. Effects of glyphosate on rhizosphere soil microbial communities under two different plant compositions by cultivation-dependent and -independent methodologies. Soil Biol. Biochem., 41:505-513, 2009.

NYE, P.H. Changes of $\mathrm{pH}$ across the rhizosphere induced by roots. Plant Soil, 61:7-26, 1981.

OLIVEIRA JÚNIOR, R.S.; CONSTANTIN, J.; COSTA, J.M.; CAVALIERI, S.D.; ARANTES, J.G.Z.; ALONSO, D.G.; ROSO, A.C. \& BIFFE, D.F. Interação entre sistemas de manejo e de controle de plantas daninhas em pósemergência afetando o desenvolvimento e a produtividade da soja. Planta Daninha, 24:721-732, 2006.

PAYNEL, F.; MURRAY, P.J. \& CLIQUET, J.B. Root exudates, a pathway for short-term transfer from clover and ryegrass. Plant Soil, 229:235-243, 2001.
RAIJ, B.; ANDRADE, J.C.; CANTARELLA, H. \& QUAGGIO, J.A. Análise química para avaliação da fertilidade de solos tropicais. Campinas, Instituto Agronômico de Campinas, 2001. 285p.

SCHJOERRING, J.K.; HUSTED, S. \& MATTSON, M. Physiological parameters controlling plant-atmospheric ammonia exchange. Atmost. Environ., 32:491-498, 1998.

STRATTON, G.W. \& STEWART, K.E. Effects of the herbicide glyphosate on nitrogen cycling in an acid forest soil. Water Air Soil Pollut., 60:231-247, 1991.

SUBBARAO, G.V.; ISHIKAWA, T.; ITO, O.; NAKAHARA, K.; WANG, H.Y. \& BERRY, W.L. A bioluminescence assay to detect nitrification inhibitors released from plant roots: A case study with Brachiaria humidicola. Plant Soil, 288:101-112, 2006a.

SUBBARAO, G.V.; ITO, O.; SAHRAWAT, K.L.; BERRY, W.L.; NAKAHARA, K.; ISHIKAWA, T.; WATANABE, T.; SUENAGA, K.; RONDON, M. \& RAO, I.M. Scope and strategies for regulation of nitrification in agricultural systems: challenges and opportunities. Crit. Rev. Plant Sci., 25:1-33, 2006b.

SUBBARAO, G.V.; RONDON, M.; ITO, O.; ISHIKAWA, T.; RAO, I.M.; NAKAHARA, K.; LASCANO, C. \& BERRY, W.L. Biological nitrification inhibition (BNI) - is it a widespread phenomenon? Plant Soil, 294:5-18, 2007a.

SUBBARAO, G.V.; TOMOHIRO, B.; MASAHIRO, K.; ITO, O.; SAMEJIMA, H.; WANG, H.Y.; PEARSE, S.J.; GOPALAKRISHNAN, S.; NAKAHARA, K.; ZAKIR HOSSAIN, A.K.M.; TSUJIMOTO, H. \& BERRY, W.L. Can biological nitrification inhibition (BNI) genes from perennial Leymus racemosus (Triticeae) combat nitrification in wheat farming? Plant Soil, 299:55-64, 2007b.

SUBBARAO, G.V.; WANG, H.Y.; ITO, O.; NAKAHARA, K. \& BERRY, W.L. $\mathrm{NH}_{4}{ }^{+}$triggers the synthesis and release of biological nitrification inhibition compounds in Brachiaria humidicola roots. Plant Soil, 290:245-257, 2007c.

SUBBARAO, G.V.; NAKAHARA, K.; HURTADO, M.P.; ONO, H.; MORETAB, D.E.; SALCEDO, A.F.; YOSHIHASHI, A.T.; ISHIKAWA, T.; ISHITANI, M.; OHNISHIKAMEYAMA, M.; YOSHIDA, M.; RONDON, M.; RAO, I.M.; LASCANO, C.E.; BERRY, W.L. \& ITO, O. Evidence for biological nitrification inhibition in Brachiaria pastures. PNAS, 106:17302-17307, 2009.

TIMOSSI, P.C.; DURIGAN, J.C. \& LEITE, G.J. Formação de palhada por braquiárias para adoção do Sistema Plantio Direto. Bragantia, 66:617-622, 2007.

UREN, N. Types, amounts and possible function of compounds released into the rhizosphere by soil-grown plants. In: PINTON, R.; VARANINI, Z. \& NANNIPIERI, P., eds. The rhizosphere biochemistry and organic substances at the soil-plant interface. Boca Raton, CRC Press, 2007. p.1-21.

VALLIS, I. \& KEATING, B.A. Uptake and losses of fertilizer and soil nitrogen in sugar crops. Proc. Aust. Soc. Sugar Cane Technol., 16:105-113, 1994. 